ISSN:2656-4270 (Online) 1410-4466 (Print) Accredited by Ministry of Research, Technology, and Higher Education with the ranking of Sinta (S4) SK NO.28/E/KPT/2019, 26th September 2019
Buletin Penelitian Sosial Ekonomi Pertanian Fakultas Pertanian Universitas Haluoleo

2020:22(1):32-42

http://ojs.uho.ac.id/index.php/sosek

doi: http://dx.doi.org/10.37149/sosek.v22i1.12120

\title{
LOCAL WISDOM OF THE AGRICULTURE SYSTEM IN TUKANG BESI ISLANDS COMMUNITY (Case Study at Wangi-Wangi Island Wakatobi Regency)
}

\author{
Harviyaddin $^{\text {() }}$, Hidrawati $^{\left.2^{*}\right)}$, La Ode Safuan ${ }^{3)}$, Nur Arafah $^{4)}$, Abdul Manan ${ }^{4)}$ \\ ${ }^{1}$ Department of Agricultural Science, Postgraduate Program, University of Halu Oleo, Kendari 93232 \\ ${ }^{2}$ Department of Agribusiness, University of Halu Oleo, Kendari 93232 \\ ${ }^{3}$ Department of Agrotechnology, University of Halu Oleo, Kendari 93232 \\ ${ }^{4}$ Department of Environmental Science, University of Halu Oleo, Kendari 93232
}

${ }^{*}$ Corresponding author. yadin.wktb@gmail.com

To cite this article:

Harviyaddin, H., Hidrawati, H., Manan, A., Sabaruddin, L., Safuan, L., Arafah, N., \& Mappasomba, M. (2020). Local Wisdom of The Agriculture System in Tukang Besi Islands Community (Case Study at Wangi-Wangi Island Wakatobi Regency). Buletin Penelitian Sosial Ekonomi Pertanian Fakultas Pertanian Universitas Haluoleo, 22(1), 32 - 42. doi:http://dx.doi.org/10.37149/bpsosek.v22i1.12120

Received: May 04, 2020; Accepted: August 27, 2020; Published: August 31, 2020

\section{ABSTRACT}

Local wisdom of the community in the agricultural system gains a large number of interests in the field of research because of its ties to the aspects of ecology, economy, and socio-culture. This study aims to analyze Tukang Besi islands community's local wisdom and its role in sustainable agriculture systems. This research was conducted from May to December 2018. The data was collected through orientation, exploratory, and confirmative studies, thus analyzed in qualitative descriptive method by describing local wisdom and its role in sustainable agricultural system. The results showed that agriculture is a way of life for the community in Wangi-Wangi Island. The practice of agronomic local wisdom in cassava cultivation is ecologically, economically, socially and culturally appropriate. Local wisdom is practiced starting from the selection and determination of land, land clearing, planting, maintenance and harvesting. Local wisdom of the Wangi-Wangi Island community in a sustainable agricultural system has three roles: 1) ecologically by maintaining the preservation of land resources through conservation in the welli'a and rawu'a systems by integrating plant diversity, mulching, and fallowing; 2) economically by maintaining the sources of life such as food reserves and alternative sources of income through the collection of forest and marine products; and 3) socially by maintaining a socio-cultural system in harmonious relations between the sara and the community and by maintaining the stability of production.

Keywords: agriculture; islands; local wisdom; Tukang Besi

\section{INTRODUCTION}

Increase in food production has received major attention in the agricultural system in line with an increase in population growth. This is done through a modern agricultural system that relies on the use of mechanization and synthetic chemicals (fertilizers, pesticides and herbicides) so that farmers depend on prices and production facilities. On the other hand, chemical residues can cause soil and water pollution. This has resulted in a decline in the productivity of the agricultural sector because the application of superior seeds, fertilizers, and pesticides has reached saturation point at an all times high and agricultural land is exhausted (land fatigue) (Arifin, 2001). These problems require the most appropriate agricultural system so that production can be sustainable and the environment remains preserved. Agricultural systems need to include environmental aspects (Irsal Las \& Setiyanto, 2006) and local wisdom (Salikin, 2003). This concept is known as a sustainable agricultural system that is ecologically responsible, economically feasible, socially just, humanitarian and adaptable to all developments (Reijntjes, Haverkort, \& Waters-Bayer, 1999).

Local wisdom in agricultural systems develops according to natural conditions because society and nature are interconnected. Currently practiced local wisdom is the result of trials and experiences that have been proven to ensure the survival of farmers, and applicable, in accordance 
with ecological, social, economic, and environmentally friendly conditions. However, the productivity is low because it follows nature's rules. It needs to be combined with modern knowledge to increase productivity, such as the Morenene tribe in the agricultural system (Arafah, 2002), Balinese people with wuku for determining the timing of planting and subak (Martiningsih, 2012), and the Moluccan people with sasi in the fishing management system (Judge \& Nurizka, 2008).

The Tukang Besi Islands or commonly known in present day as the Wakatobi Islands has unique natural resources and local wisdom to develop. This can be seen in the Decree of the Minister of Forestry Number 393/Kpts/96 dated 30 July 1996 concerning the Zoning of the Tukang Besi Islands National Park. Also on the concept of local community wisdom such as motika and kaindea in forest management (Manan A., 2000). Due to a population pressure and development interests, areas designated for conservation were converted into residential areas and land resources and local wisdom in the agricultural system become threatened.

Local wisdom and global wisdom in the agricultural system is not something that always ends in one particular choice but the combination between the two needs to be synthesized to produce the correct formula. Local wisdom can be the vortex of agricultural development (Sjamsir, 2017) so that agricultural sustainability values can be realized. A number of local knowledge and wisdom in the agricultural system need to be scientifically explored in order for the benefits can be presented and applied by the wider community. Based on this, it is deemed necessary to conduct a study on the exploration of local community wisdom in the agricultural system.

This study aims to describe the local wisdom of the Wangi-Wangi Island community, and to describe its role in a sustainable agricultural system. It is hoping that this research can be useful as information material for the community, as a comparison for future researchers about local wisdom and its role in sustainable agricultural systems as well as an input for stakeholders in developing local agricultural potential as one of the pillars of regional development.

\section{MATERIALS AND METHODS}

This study was conducted from May to December 2018. The research took place in Wakatobi Regency, Southeast Sulawesi Province. The location of the case study is at Wangi-Wangi Island, one of the islands in the Tukang Besi/Wakatobi Islands. This area is in a geographic position of 4,300-60 South Latitude and 1.200-1.250 East Longitude at an altitude of 0-275 meters above sea level. There are three areas as sample villages, namely Tindoi Village in Wangi-Wangi District and in Liya Togo Village and Wungka Village in South Wangi-Wangi District. The selection of sample villages was based on the consideration that (1) most of the people in the sample areas live from agriculture (95\%), and still practice traditional farming systems; and (2) the geographic, demographic, and socioeconomic conditions of the community which are considered to represent the conditions of the people of Wangi-Wangi Island.

Population of this study is the people who are considered to represent and know the problem arising from the study, with the criteria of the head of the family (household) who make a living as cassava farmers. Cassava is widely cultivated by the community, $89.5 \%$ of the total area of the food crops. This plant has social and economic value for the people of Wangi-Wangi Island. Determination of the sample was carried out in two stages: stage 1 is the determination of the sample was carried out deliberately (nonprobability) based on purposive sampling. Samples were taken deliberately based on research objectives with due regard to environmental conditions and a balanced sample allocation (Soehartono, 2000), 11 people were assigned as key informants based on their status and role in society. Stage 2 data collection in the field with the aim of finding out the practice of local wisdom and it is role in sustainable agricultural systems. The sample was determined by simple random sampling with consideration of homogeneous conditions (Martono, 2015). There were 25 households in each sample village, so the total sample was 75 households.

Data collection was carried out through orientation, exploration, and confirmation studies packaged in data triangulation techniques. Orientation study are a field recognition study from secondary data such as literature surveys from related agencies. Furthermore, exploratory study is understanding the phenomena in the field for collecting data relevant to the research objectives. Then it is checked through a confirmation study, which is direct interviews with the community using structured questionnaires and informal in-depth discussions. The data obtained were tabulated and analyzed descriptively, providing detailed and comprehensive descriptions (Agusta, 2003) about the sequence of farmers activities in agricultural systems and explaining the role of local wisdom in sustainable farming systems. 


\section{RESULTS AND DISCUSSION}

\section{Agroecological, Social, and Economic Characteristics of Wangi-Wangi Island Community Agroecological Characteristics}

The total area of Wangi-Wangi Island is $381.63 \mathrm{Km}^{2}$ or $38,163 \mathrm{Ha}$ (BPS, 2018d). The land surface is rugged to hilly, and during the dry season it cracks. Data (BPS, 2018a) also states that the effective soil depth is $90-60 \mathrm{~cm}$ covering an area of 6,626 ha, a depth of $60-30 \mathrm{~cm}$ covering an area of $6997 \mathrm{ha}$, and a depth of $<30 \mathrm{~cm}$ covering an area of 3,127 ha. Furthermore, the slope of $0-2 \%$ covering an area of 12,332 ha, $2-15 \%$ covering an area of 4,610 ha, $15-40 \%$ covering an area of 15,660 , and slope $>40 \%$ covering an area of 6,051 ha. The hydrological condition is influenced by water in caves and from the jungle. The water is used for bathing, washing and clean water sources. Agricultural systems rely on rainwater as the only source of water. Based on the Oldeman climate classification, Wangi-Wangi Island is categorized as E2 climate because it has an average of 2 wet months and 4 dry months. The climate is controlled by the movement of air masses. The west monsoon is controlled by the Southwest wind which brings lots of rain. This season falls from December to April. The East Season brings little rain controlled by the Northeast Wind. This season falls from June to October.

Data from the Agriculture, Forestry, Plantation and Livestock Office of Wakatobi Regency in 2018 shows that the total area of smallholder plantations is $1,726.80$ ha which is dominated by coconut (Cocos nucifera L.) 1.006,00 ha, cashews (Anacardium occidentale L.) 305,00 ha, coffee (Coffea spp) 35,00 ha, cacao (Teobroma cacao L.) 26,00 ha, and cloves (Eugenia aromatica O.K) 4,00 ha. The main commodity of food crops is corn (Zea mays L.) with a productivity of 0.79 tons haand cassava (Manihot utilissima L.) with a productivity of 7.04 tons ha ${ }^{-1}$. Also endeavored to make vegetables to support family nutrition sources with productivity levels ranging from $0,10-1,46$ ton ha ${ }^{1}$. Food crops, especially cassava, are cultivated in welli'a and rawua land. Welli'a land is more acidic than rawu'a. C-organic, CEC, phosphorus, potassium, and calcium in welli'a land were higher than in rawu'a, but nitrogen in rawu'a was higher. The soil texture in welli'a is dust and rawu'a is dusty clay. Welli'a land has a high diversity of Arbuscular Mycorrhizal Fungi (AMF) compared to rawu'a. For more details, a sample of the results of soil analysis is presented in Table 1.

Table 1. The condition of cassava cultivation in Wangi-Wangi Island

\begin{tabular}{llccc}
\hline Soil Characteristic & \multicolumn{1}{c}{ Parameter } & Welli'a & Rawu'a $^{\prime}$ & Status $^{3}$ \\
\hline Chemical $^{1}$ & $\mathrm{pH}$ & 5,44 & 5,69 & Acidic - less acidic \\
& Nitrogen (\%) & 0,28 & 0,56 & Low - high \\
& Phosporus (ppm) & 15,12 & 7,56 & Low \\
& Potassium (me/100 gram) & 0,28 & 0,14 & Low \\
& CEC (me/100 gram) & 12,60 & 14,10 & Low \\
& C-Organic (\%) & 1,79 & 1,40 & Low \\
& Calcium (me/100 gram) & 2,30 & 1,80 & Low \\
\hline Physical $^{1}$ & Texture class & Dust & Dusty clay & - \\
Biological $^{2}$ & Genus AMF & & & - \\
& Gigaspore & 2 & - & - \\
& Acaluspore & 1 & - & - \\
\hline
\end{tabular}

Source: ${ }^{1}$ Results of analysis at Basic Chemistry Laboratory Halu Oleo University, (2018); ${ }^{2}$ Results of analysis at Inoculant Unit Laboratory, Faculty of Agriculture Halu Oleo University, (2018) ; ${ }^{3}$ Criteria for soil research staff (1983) in Hardjowigeno, S.,(1995).

\section{Socio-Economic Characteristics}

Wangi-Wangi Island consists of two districts, namely Wangi-Wangi and South Wangi-Wangi districts. Wangi-Wangi district has 20 villages/subdistricts with 29,924 inhabitants (BPS, 2018b) and South Wangi-Wangi district has 21 villages/subdistricts with 33,277 inhabitants (BPS, 2018c). The main livelihoods are farming, fishing, trading, and a small portion of civil servants, service businesses and carpentry. In 2018, the agricultural sector still dominated the contribution to Wakatobi Regency Gross Regional Domestic Product (GRDP), especially Wangi-Wangi Island. This sector contributes around 37.48 percent (BPS, 2019) indicating that the community socio-economic activities are still very dependent on agricultural and fishery products.

As the capital of Wakatobi Regency, Wangi-Wangi Island has relatively adequate social and economic infrastructure for the community. Educational facilities are available starting from the level 
of early childhood to tertiary education. Health facilities are also available, ranging from Integrated Service Posts in subvillages/neighborhoods to Regional General Hospital type B. Social facilities are available such as special places of worship for Muslim (mosques), meeting halls, tourism and cultural sites in almost all villages/subdistricts. The availability of economic facilities includes markets and financial institutions. Transportation means are in the form of land, sea and air transportation and means of communication is in the form of cellular telecommunication networks.

The community social interactions are bound by religious and customary norms firmly held by sara. During the sultanate period, sara was an autonomous government system that carried out legislative, judicial and executive functions. Sara's legislative function is led by meantuu with the assistance of bonto, kontabitara, pangalasa, djurubasa, meantuu-meantuu and wati. The judicial function of the sara is carried out by bonto assisted by a bobato with the highest decision at the consensus agreement. The designation and number of meantuu-meantuu in bobato are adjusted to the characteristics of each sara in Wangi-Wangi Island. Sara's executive function is divided into two, namely Sara Hokumu and Sara Adati. Sara Hokumu is in charge of religious matters, while Sara Adati is in charge of social affairs.

\section{Local Wisdom in Agricultural Systems Land Selection}

Land is selected based on its fertility with indicators: vegetation diversity, soil depth, and the amount of soil attached to the rock. The fertile soil is characterized by balande and karihu-rihu vegetation (Lantana camara L.) and less fertile soil is characterized by cogongrass (Imperata cilindrica L.) and komba-komba (Eupatorium odoratum L.). The depth of the soil is identified from the sound of the ground knocked with a small crowbar. The soil attached to the rock at ground level is identified by removing some of the rock that has risen to the surface. Based on the depth of the soil, agricultural land (koranga) divided into three, namely:

1. Kaindea with an effective depth of 30-90 cm. This forest, by Wanci and Mandati communities is controlled by sara (kaindea $u$ sara) while by Liya community is controlled by a certain family (kaindea u santuha). Kaindea conversion is processed through the rawu'a system. Rawu'a system is a land made of mounds/bumbunan for cassava cultivation. Apart from cassava, long-term crops are also planted.

2. Motika with an effective depth of $<30 \mathrm{~cm}$. Motika conversion is processed through welli'a system. This forest is controlled by sara and can not be converted unless illegally.

3. Padangkuku with an effective depth of $<10 \mathrm{~cm}$. Padangkuku conversion is processed through welli'a system. Welli'a system utilizes a slash and burn system.

Selected land is then marked (sehai'a). Sehai'a is done by cutting a few shoots of vegetation, then crushing them on a certain day (considered as a blessed day by community). Thus the land is cleared after seven days.

\section{Land Clearing}

Rawu'a cleaning is done by cutting the vegetation (sewali'a) with a machete. Clearing of welli'a land by removing vegetation (owu'a) then continued by cutting down trees (welli'a) and burning (sulaa). Welli'a is cutting trees as high as $150-200 \mathrm{~cm}$ as a support for climbing red beans (Phaseolus vulgaris L.) and uwi (Dioscorea spp). Kokapa (fitex copacus) and other large trees, are maintained as building materials and/or animal perches (toropangaa). The trees were pruned as needed. After the first rains at the start of the season, burning was carried out. Sulaa is the final activity of land clearing by burning dry trees cuts. Sulaa begins by making ilaran or ati'a (a clean path that serves to inhibit or cut the spread of fire) on the edge of the land as needed, meaning that it is estimated that the fire will no longer spread to other parts. Sulaa starts from the direction opposite to the wind direction so that the fire can be controlled and the burning is finished. If there is a cut that has not been completely burned, it is collected and then burned again.

\section{Planting Preparation}

Soil processing (sangko'a) is done by hoeing, then making a mound (rawu'a) with an average height of $30 \mathrm{~cm}$ and an average area of $30 \mathrm{~cm} \times 30 \mathrm{~cm}$. If the ground is rocky, then rawu'a is modified or removed altogether. Rawu'a modification starts with looking for gaps in the rock that contain soil. If the gap is small, then try to enlarge it and remove the soil. The hole is filled with cut leaves, shrubs or grass and coated with biodegradable household waste. The top is given soil or fine gravel then covered with cuttings of shrubs or grass. The top part of the mound will be given padangkuku, coconut leaves or waste as mulch. 
After the soil is processed, cassava stem cuttings are prepared. Stem cuttings were selected based on their physical condition, age of harvest, origin of cuttings and production objectives. Currently farmers are still cultivating two local and ten introduced cultivars as shown in Table 2.

Table 2. Consumption priority, cuttings origin, and harvest age of cassava at Wangi-Wangi Island

\begin{tabular}{lccc}
\multicolumn{1}{c}{ Local Cultivar } & Consumption Priority & Cuttings Origin & Harvest Age \\
\hline Basitele mokuri & & Introduksi & 3 months \\
Salbiah & & Introduksi & 6 months \\
Jami-Jami & Boiled & Introduksi & 6 months \\
Inggirisi & & Introduksi & 6 months \\
Basitele meha & Introduksi & 6 months \\
\hline Anda & & Local & 2 years \\
Gendi & Local & 2 years \\
Buru & & Introduced & 8 months \\
Kalambe & Introduced & 8 months \\
Santeri & Grated & Introduced & 8 months \\
Basitele mohute & & Introduced & 8 months \\
Bogoro & & Introduced & 8 months \\
\hline
\end{tabular}

A good stem cutting does not have white patches and the distance between its segments is short. Based on their age, a good cutting is at a harvest age. This age is related to the purpose of production, which is to boil and/or to grate. Good cuttingss can come from other areas, from welli'a land to rawu'a land or vice versa (bhali wuta). A good cutting is cut upside down, the top (shoot) touches the ground (below) and the top (base) stem is above. The cutting of the stem cuttings is done carefully with 3-5 touches of the machete to prevent damage. The cuttings cut 20-30 buds. The number of buds is influenced by the type of land and the planting season.

The timing of planting is based on natural phenomena, namely the position of the moon and stars, the appearance of vegetation, and the behavior of animals. In determining the planting time, the amount of rainfall in a year should be predicted beforehand. This amount is known from the concentration of clouds at the position of the Pari Star/Southern Cross (sangia) and the moon, when sangia rises to sets at the beginning of the season. The concentration of clouds around sangia has a positive correlation with the amount of rainfall. Mim year is the year with the most rainfall (2015) and year $A a$ is the year with the least rainfall. This knowledge can be seen in Table 3 below:

Table 3. Distribution of year forecast based on cloud concentrations in relation to crop yields.

\begin{tabular}{cccc}
\hline Year & Total of Wet Month & Total of Dry Month & Notes \\
\hline $\mathrm{Aa}$ & $2-4$ & $6-8$ & Drought \\
$\mathrm{Ba}$ & $4-6$ & $4-6$ & Bad crop yields \\
$\mathrm{Ha}$ & $3-5$ & $5-7$ & Fewer crop yields \\
$\mathrm{Mim}$ & $6-8$ & $2-4$ & Big harvest \\
\hline
\end{tabular}

The year forecast based on initial concentrations in Table 3 relates to the availability of rainwater as the basis for determining the appropriate planting year. The right time for planting is done a few weeks after the initial rain of the season falls. Rain will fall in the following week in relation to planting time if the sun setting distance from Cape Kapota is almost 1 meter accompanied by lightning and reddish clouds. This information is supported by the appearance of vegetation such as kalele fruit that has reached the rock (pasi). The stability of this information is supported by the behavior of animals, such as baronang (rabbit fish) fish eggs that have been fertilized for three times. Furthermore, if the sign is there and the rain has fallen, then the first planting day (belai'a) is chosen based on the calculation of the month in the sky (lunar calculation) as shown in Table 4 as follows:

Table 4. Planting time based on moon calculations in Wangi-Wangi Island community

\begin{tabular}{ccc}
\hline Plant Type & \multicolumn{2}{c}{ Planting Time } \\
\cline { 2 - 2 } & $3,9,15,21,27,30$ & Bad \\
\hline Tubers & $5,11,17,23,26,29$ & \multirow{2}{*}{$2,8,12,14,18,20,24}$, \\
\hline Corn & $1,4,7,10,13,16,19,22,25,28$ & \\
\hline Red Bean & &
\end{tabular}


The calculations in Table 4 relate to the types of crops grown. If the moon coincides with the bad month (nahasi) then planting is based on the calculation of good days and bad days. If it coincides with a bad day then planting is based on the count of good and bad hours. In general, a 910 hours range is considered good for planting. Based on its geographical position, there are two planting time zones, namely the Wanci-Mandati planting time and the Liya-Longa planting time. Wanci-Mandati planting is done at the beginning of the season, while Liya-Longa planting is carried out three months later. The cropping system (cropping pattern) is monoculture and intercropping. Intercropping begins with planting uwi (tubers), then followed with corn. When the corn has shown five leaves (tombolo), the cassava is ready to be planted. If lightning and thunder appear altogether at the same time then vegetables are planted. The system is illustrated in Figure 1.

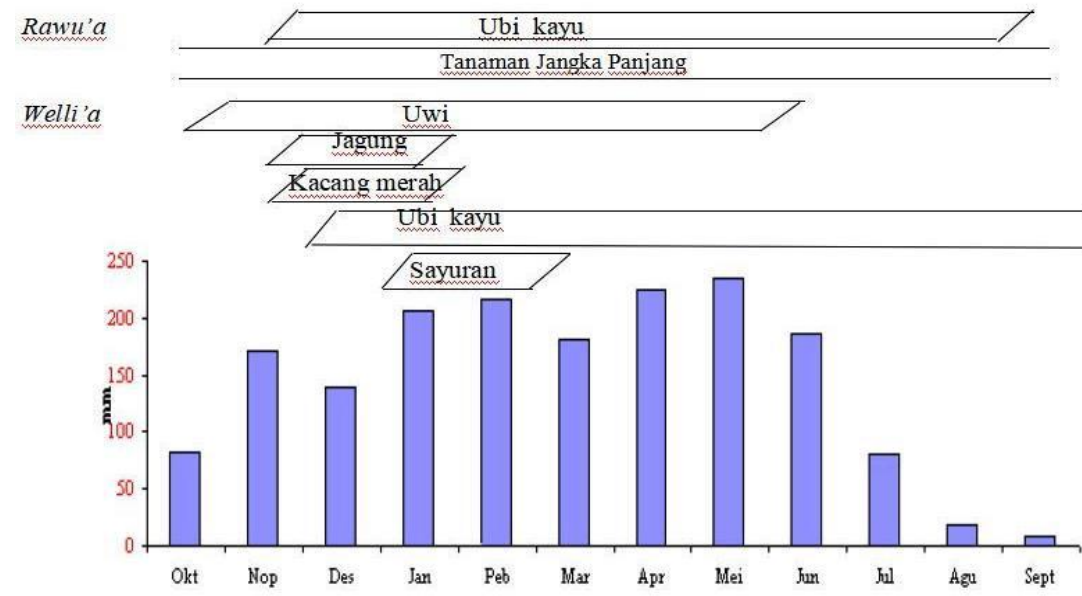

Figure 1. Illustration Diagram of the Wangi-Wangi Island community planting system

\section{Planting (hembulaa)}

Hembulaa is a direct or indirect investment of support cuttings into the land. Directly, they are immersed without using a small crowbar while indirectly, they are immersed after making the planting hole using a small crowbar. A total of 4-5 shoots are inserted into the support cuttings and then pulled up so that 3-4 buds remain. The position of the support cuttingss is influenced by the type of land and the planting season. Cuttingss that did not grow are replaced (sulele). Sulele cuttingss are relatively long to ensure the plant height becomes uniformed. Spacing and cuttingss needs are adjusted to land conditions. Rawu'a has a regular spacing and is relatively wide compared to welli'a land, so the needs for cuttings ha ${ }^{-1}$ are different.

\section{Maintenance}

Cuttingss that grow are maintained by fertilizing, controlling weeds and controlling pests (aho'a). In order to obtain a relatively large yield of cassava, only one shoot is maintained, but for the source of seedlings, 2-3 shoots are maintained. The fertilizers used are organic fertilizers such as manure, combustion residue, and soil under the house (crawl space). Weeds are controlled mechanically using ka'ofu or kali. Weed control on welli'a land is carried out selectively while in rawu'a, weeds are pulled out. Weed control is carried out at least twice during the harvest.

The pests known to farmers are grasshoppers (aria), termites (puoi), rats (woleke), ants (kesu), and rice ear bugs (wulangga). Aria appeared all of a sudden, while Puoi appears as a result of bad drainage in rawu'a that farmers do land reversal and continuous cleaning of the garden. Woleke is controlled by cleaning the garden and selecting unfavorable cassava cultivars such as kalambe and bogoro cultivars. Besides that, the land is sprinkled with rambe in several parts of the land. Rambe is a type of corals (rock) in the shape of a tongue which is very feared by rats. People have the belief to reduce attacks by using the abstinence word "waodhe" to refer to woleke. Planting is also done by closing the eyes while reciting mantras. Wulangga appears in the red bean intercropping system. Pest control uses natural enemies such as weaver ants (loho) which are placed on wellia. Kesu is controlled by watering the kalumpa pressed juice. The disease that attacks cassava is thought to be caused by a fungus with the highest attack rate during the dry season. Farmers control fungi by mulching. Pest and disease control is also carried out by sprinkling kitchen ash on the affected parts of the plant. Another way is to border the land with lines (bori) during four Jum'at days (Fridays) on the four corners of the land, first starting from the far right corner of the garden then crossing the ground with the back of a machete/crowbar while reciting mantras. The technique is described as follows: 


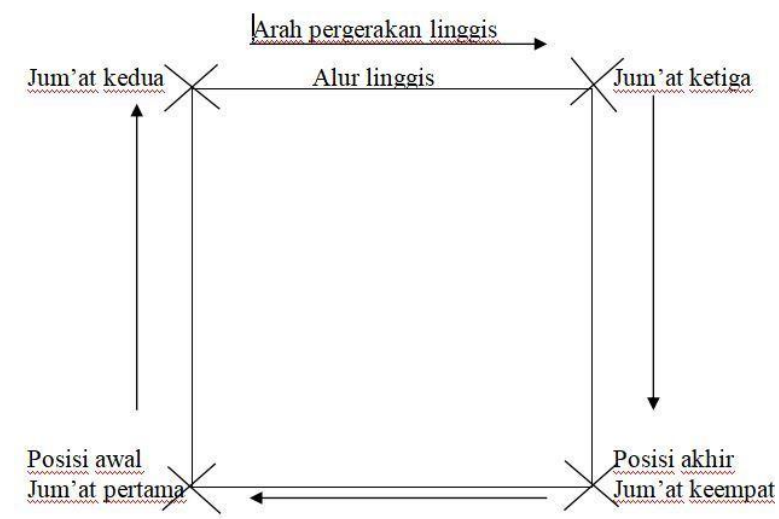

Figure 2. Sketch of plant pest and disease control workflow by using bori system

\section{Harvesting}

Harvest (kobu'a) is adjusted to the needs of the family. Except for commercial purposes, harvesting is carried out simultaneously, but this practice is rare. Harvest age ranges from 3 months to 2 years, depending on the cultivar of cassava. For grated priority, local cultivars can only be harvested when aged 2 years, while introduced species can already be harvested when aged 8 months. For boiled priority, the harvest age ranges from 3-8 months. If it has passed that age, it is prioritized to be grated. A good harvest is done before the cassava sprouts again (wulolo). Weeds are cleaned before harvesting and stems cut to a height of $30 \mathrm{~cm}$ to facilitate harvesting. The results of observations of cassava production in the respondent's garden with patch's tiles of $250 \mathrm{~cm} \times 250 \mathrm{~cm}$ can be seen in Table 6 as follows:

Table 6. Observation of cassava production at the research location

\begin{tabular}{cccc}
\hline Land Type & $\begin{array}{c}\text { Plant Height } \\
(\mathrm{cm})\end{array}$ & $\begin{array}{c}\text { Wet/Undried Weight } \\
\left(\mathrm{kg} \mathrm{tree}^{-1}\right)\end{array}$ & $\begin{array}{c}\text { Productivity } \\
\left(\text { ton ha }^{-1}\right)\end{array}$ \\
\hline Rawu'a & $230-440$ & 3,44 & 49,93 \\
\hline Welli'a & $250-320$ & 1,95 & 32,89 \\
\hline
\end{tabular}

Table 6 informs that the productivity of rawu'a is higher than that of welli'a land. Meanwhile, the productivity of Southeast Sulawesi's cassava at the farmer level reaches 1.39 tons ha- ${ }^{1}$ (BPS, 2018a). The final activity of the farming system in a year is marked with sampe'a. Sampe'a is a harvest festival in the form of a competition for the ability to collect foodstuffs (sembako) in the form of sea products, trade and agricultural products during the year entering the western planting season. Sampe'a participants register themselves to sara and the opponents are chosen by the participants. The loser is the participant who receives the most basic necessities (foodstuffs).

The series of local knowledge of the Wangi-Wangi Island community in the agricultural system indicate agronomic activities that refer to agro-centric ideas. Agrocentrism views nature (land, water and air), animals and plants and humans interact with each other (Reijntjes et al., 1999) so that it is necessary to respect each other and maintain the integrity of each component. Agronomic actions that refer to this understanding are considered to be able to support the sustainability of agricultural development due to efforts to harmonize economic, ecological and socio-cultural benefits. A number of researchers have also expressed the same opinion, including those who reveal that local wisdom contributes to environmental conservation efforts (Niman, 2019), and supports food security efforts (Martiningsih, 2012; Riptanti, Masyhuri, Irham, Suryantini, \& Mujiyo, 2018). Meanwhile, this research also reveals that local wisdom can contribute to efforts to preserve the socio-cultural values that become the way of life of the local community.

\section{The Role of Local Wisdom towards Sustainable Agriculture Systems}

\section{Ecological Sustainability}

Ecological sustainability means that the quality of natural resources is maintained and the overall capacity of the agroecosystem from humans, plants and animals to soil organisms is enhanced (Reijntjes et al., 1999). In order to maintain the sustainability of land resources and agroecosystems, the role of local knowledge of the Wangi-Wangi Island community in a sustainable 
agricultural system is discussed in the conservation aspect. Conservation is the preservation of resources that are managed without time limits or sustainable use. Therefore, the land should be used as needed so that the nutrients can be used in the next planting season. All activities carried out by farmers are always based on natural phenomena to maintain the sustainability of land resources such as selecting land, determining planting time to harvesting on welli'a land. The main function of welli'a is to provide climbing plants for red beans and tubers (uwi), accelerate succession, as a reserve for animal feed, firewood, and a source of medicine, microclimate management and localize the nutrient cycle.

Accelerated succession occurs because the vegetation in this system is not cleared away, so that new shoots can grow. Welli'a can be pruned for animal feed or a source of mulch. If welli'a dies then it is used as a climbing plant or firewood reserve. The welli'a land has large trees as building materials for houses and perches of various types of birds (toropangaa) so that there are bird droppings and food scraps (seeds) around it. Bird droppings and food scraps can supply nutrients and as a source of seeds. These seeds can increase the diversity of plants in welli'a. According to the farmers, toropongaa can reduce the population of snakes and rats. In addition, micro climate is also managed in the presence of toropongaa. These trees can reduce temperature and wind speed, prevent water evaporation from the ground, and absorb the magnetic energy from pouring rainwater. Besides, good climate management can reduce fungal attack. Furthermore, pests and diseases are controlled agronomically and agro-centrally.

The nutrient cycle in welli'a land is localized through nutrient pumping. Welli'a has deep roots to bring nutrients to the soil surface in the form of litter fall (mulch). If the mulch is broken down by microorganisms, plants with shallow roots can be used. This results in optimal availability of nutrients and balances the nutrient cycle. In addition, there are red beans that are symbiotic with rhizobium bacteria to fixate $\mathrm{N}$ from the air to help intercropping plants. However, Table 1 shows low level of $\mathrm{N}$ in welli'a land compared to rawu'a, due to burning and abundance of phosphorus as a result of association with AMF. Table 1 also shows the existence of AMF diversity on welli'a land compared to rawu'a. See Figure 3) below:

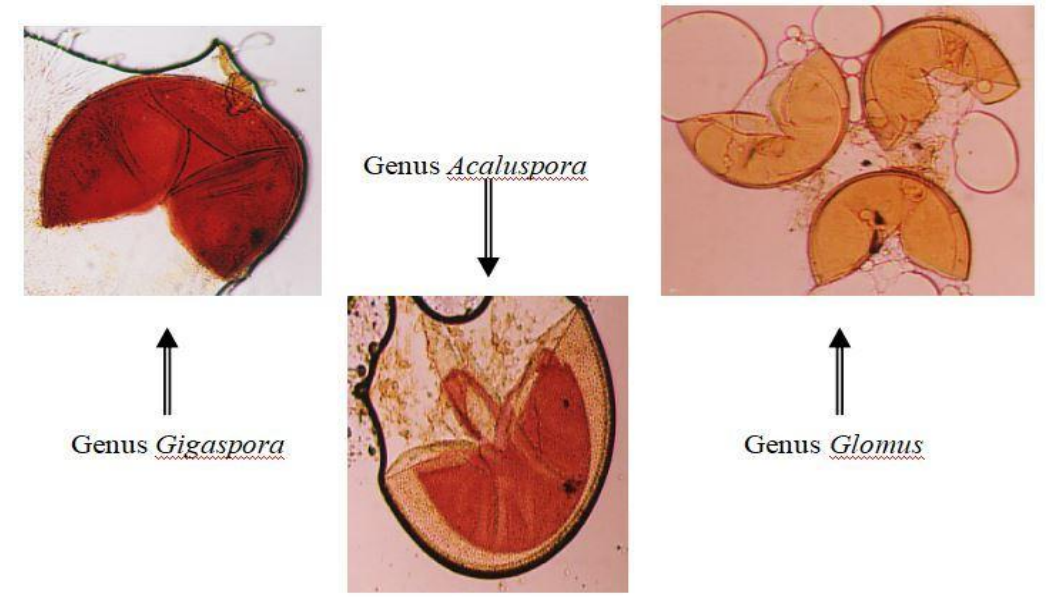

Figure 3. Genus Mycorrhiza on cassava stands at Wangi-Wangi Island

Researchers suspect that the diversity of AMF in welli'a land is due to burning and/or vegetation diversity. This assumption needs further investigation.

\section{Economic Sustainability}

Economic sustainability can be measured not only in direct agricultural products but also in terms of functions such as conserving natural resources and minimizing risks (Reijntjes et al., 1999). Economic sustainability means that farmers get enough income to return the labor and costs incurred in the farming system. Therefore, the agricultural system should provide life insurance so that farmers are able to design the future of their family. Household income from farming is considered sufficient to buy daily necessities because there is no use and dependence on inorganic fertilizers, plant protection drugs, and mechanization to ensure that production costs are low and economically profitable. The mechanization equipment used is a hoe, while the source of the seeds comes from their land, and the attack of pests and diseases is prevented agronomically and agrocentrically.

Welli'a land allows harvesting more than once, but planting is only done 1-2 times. This practice is economically profitable and can minimize the risk of crop failure due to the variety of crops harvested. To strengthen this, apart from welli'a land, farmers will also cultivate rawu'a land which can 
be harvested continuously so that food reserves will remain throughout the year. The selling value of the production (harvest) is used to meet household needs, health costs, and social funds (hopobhoka) at family events. Economic security is strengthened by gathering forest products, collecting marine products and migrating and selling livestock.

Forest for the community is a source of life, either directly or indirectly. Directly, forest is used as a source of firewood, building materials, animal feed, natural food, vegetables, fruits, animal poison and a source of medicines. Indirectly, forests have a function to store water and maintain the rainfall cycle.

Harvesting marine products such as shellfish, sea urchin, and fish using traditional fishing gear. Fishing gear used such as nets, fishing rods, traps (polo), and botanical fish poison such as towole and pandita. The collection of marine products still pays attention to natural phenomena to maintain the sustainability of the resources. For some respondents, this business was not sufficient for their needs, so they occasionally harvested marine products by bombing so that marine resources are now under threat.

\section{Socio-Cultural Sustainability}

Socio-cultural preservation is a form of way of live integrity in the agricultural system as a farming culture that ensures social interaction. For this reason, the role of local wisdom of the community of Wangi-Wangi Island in a sustainable agricultural system is viewed from the sociocultural system in community interactions and awareness of control of agricultural land and production security. The role of sara concerns two aspects, namely the spiritual aspect and the social aspect. These two aspects harmonize the relationship between the sara and community in the agricultural system. This relationship is marked by the image and myth of sara as a representative of the supernatural powers that control the land so that sara's decision is absolute and binding. The option for people who do not comply is to leave the area of customary law. This causes sara's charismatics to remain sustainable.

Land distribution is a form of social justice in the agricultural system related to social status, such as the area of land cultivated. Land controlled by the community is a state land that is managed by sara in a manner of which is communal, meaning that customary land cannot be traded and transferred to other people who are not in the same family (kaomu). In order to guarantee this, the following land conception is known:

1. Wuta kedema, is a type of land controlled with temporary ownership. It can be owned by other people if no longer cultivated such as land borders with customary law areas (kaselapa) and padangkuku.

2. Wuta moneaa, is a type of land controlled in the form of use rights and property rights. The land can change hands because it has a certificate.

This concept can eliminate land conflicts to maintain social relations. Social unrest can threaten the whole social system, including the agricultural system (Reijntjes et al., 1999). However, due to population growth and Wangi-Wangi Island's position as the regency capital, land conversion for settlement is so rapid that land conflicts are currently high.

Sara's success in maintaining its existence as a center of power depends on the production surplus generated according to the willingness and ability of the farmers. The members of the sara are selected based on the hierarchy and lineage with ability as the main consideration. This is because sara members, as well as certain herbalists (parika), have the power of parika knowledge if they are still in the lineage, so that indirectly, sara spurs and maintains the stability of production. If crop yields are reduced, failures or there is an outbreak of pests and diseases, the officials responsible for the crop or controlling pests/diseases will be replaced, at least a warning will be given beforehand. The community will provide a portion of the harvest according to the harvest conditions. If the harvest is successful, the best crop will be given to sara, but if the harvest fails, the worst harvest will also be given to sara. To strengthen the role of sara and community in ensuring the sustainability of production, sampe'a is held. Sampe'a winners will gain fame and social status. This principle makes sara and community support each other in maintaining their status and values (charisma). Sara's local and charismatic knowledge is currently experiencing a shift in value due to modernization. The presence of a state government system at the sara level causes its role and function to begin to weaken, however, the government continues to strive to preserve the socio-cultural system through social and community interactions by forming customary institutions as government partners in social development.

The existence of customary institutions needs to be appreciated in an effort to preserve local wisdom values. This study shows that customary institutions (sara) have roles and responsibilities that determine the implementation of local wisdom systems. Customary institutions also play a role in 
preserving local wisdom (Alus, 2014), preserving land resources (Toulmin, 2009), agents of social and environmental change (Adano, Dietz, Witsenburg, \& Zaal, 2012). On the basis of this role, customary institutions need to be increased in capacity so that they can be accelerated as locomotives in maintaining the values of local wisdom.

\section{CONCLUSIONS AND SUGGESTION}

The results of this study revealed that agriculture is a way of life for the people of WangiWangi Island. Local wisdom is applied in cassava cultivation ecologically, economically, socially and culturally. This knowledge is applied from the selection and determination of land, land clearing, planting, maintenance and harvesting. The role of local wisdom of the Wangi-Wangi Island community in a sustainable agricultural system, is ecologically maintaining the preservation of land resources through conservation in the welli'a system by integrating plant diversity, mulching and grounding. In economic aspect, local wisdom maintains the sources of life such as food reserves and alternative sources of income through the collection of forest and marine products. In social aspect, it maintains a socio-cultural system in harmonious relations between the sara and community as well as maintains the stability of production. This study suggests the need for further study regarding the scientific knowledge of the agronomic local community of Wangi-Wangi Island to support sustainable agricultural development.

\section{ACKNOWLEDGMENTS}

Thank you to the informants who have been willing to provide research information during the research. Thank you also to government officials and local institutions in Wangi-Wangi Island, Wakatobi Regency and all those who have helped of the research.

\section{REFERENCES}

Adano, W. R., Dietz, T., Witsenburg, K., \& Zaal, F. (2012). Climate change, violent conflict and local institutions in Kenya's drylands. Journal of peace research, 49(1), 65-80.

Agusta, I. J. P. P. S. E. L. P., Bogor. (2003). Teknik Pengumpulan dan Analisis Data Kualitatif. 27.

Alus, C. (2014). Peran lembaga adat dalam pelestarian kearifan lokal suku sahu di desa balisoan kecamatan sahu kabupaten halmahera barat. Jurnal Acta Diurna Komunikasi, 3(4).

Arafah, N. (2002). Pengetahuan Lokal Suku Moronene dalam Sistem Pertanian di Sulawesi Tenggara.

Arifin, B. (2001). Pertanian Era Transisi. Lampung: Universitas Lampung.

BPS. (2018a). Hasil Survei Pertanian Antar Sensus (SUTAS) 2018 Provinsi Sulawesi Tenggara. In B. S. Tenggara (Ed.), (Vol. 74530.1807). Kendari: Badan Pusat Statistik Propinsi Sulawesi Tenggara.

BPS. (2018b). Kecamatan Wangi-Wangi Dalam Angka Tahun 2018, Wangi-Wangi Subdistrict in Figure 2018. In B. K. Wakatobi (Ed.). Wakatobi: Badan Pusat Statistik Kabupaten Wakatobi.

BPS. (2018c). Kecamatan Wangi-Wangi Selatan dalam Angka Tahun 2018, Wangi-Wangi Selatan Subdistrict in Figure 2018. In B. K. Wakatobi (Ed.), (Vol. 74070.1804). Wakatobi: Badan Pusat Statistik Kabupaten Wakatobi.

BPS. (2018d). Wakatobi Dalam AngkaTahun 2018, Wakatobi Regency in Figure 2018. In B. K. Wakatobi (Ed.), (Vol. 74070.1803). Wakatobi: Badan Pusat Statistik Kabupaten Wakatobi.

BPS. (2019). Kabupaten Wakatobi dalam Angka, Wakatobi Regency in Figure 2019. In BPS (Ed.). Kabupaten Wakatobi: BPS Kabupaten Wakatobi.

Irsal Las, K. S., \& Setiyanto, A. J. J. L. P. (2006). Isu dan pengelolaan lingkungan dalam revitalisasi pertanian. 25(3), 107.

Judge, Z., \& Nurizka, M. J. L. J. (2008). Peranan Hukum Adat Sasi Laut Dalam Melindungi Kelestarian Lingkungan di Desa Eti Kecamatan Seram Barat Kabupaten Seram Bagian Barat. 6(1), 18037.

Manan A., d. A. N. (2000). Studi Pengelolaan Sumber Daya Alam Berbasis Kearifan tTadisional di Pulau-Pulau Kecil (Studi Kasus di Pulau Wangi-Wangi Kabupaten Buton Sulawesi Tenggara). Jurnal Manusia dan Lingkungan PPLH-UGM, VII (2), 71-80.

Martiningsih. (2012). Pelestarian Subak Dalam Upaya Pemberdayaan kearifan Lokal menuju ketahanan pangan dan hayati. Jurnal Bumi Lestari, 12(2), 303-312.

Martono, N. (2015). Metode Penelitian Sosial: Konsep-Konsep Kunci. Jakarta: Rajawali Press. 
Niman, E. M. (2019). Kearifan lokal dan upaya pelestarian lingkungan alam. Jurnal Pendidikan dan Kebudayaan MISSIO, 11(1), 91-106.

Reijntjes, C., Haverkort, B., \& Waters-Bayer, A. (1999). Pertanian masa depan: pengantar untuk pertanian berkelanjutan dengan input luar rendah: Kanisius.

Riptanti, E., Masyhuri, M., Irham, I., Suryantini, A., \& Mujiyo. (2018). The development of leading food commodities based on local wisdom in food-insecure area in East Nusa Tenggara Province, Indonesia. Applied Ecology And Environmental Research Journal, 16, 7867-7882.

Salikin, K. A. (2003). Sistem pertanian berkelanjutan: Kanisius.

Sjamsir, Z. (2017). Pembangunan Pertanian dalam Pusaran Kearifan Lokal (Vol. 1): SAH MEDIA.

Soehartono, I. (2000). Metode Penelitian Sosial: Suatu Teknik Penelitian Bidang Kesejahteraan Sosial dan Ilmu Sosial Lainnya. Bandung: PT Remaja Rosdakarya.

Toulmin, C. (2009). Securing land and property rights in sub-Saharan Africa: the role of local institutions. Journal Land use policy, 26(1), 10-19. 